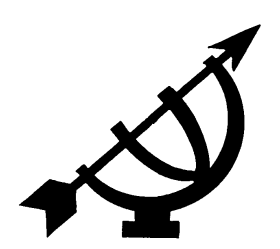

\title{
Combat organ trafficking - reward the donor or regulate sales ${ }^{1}$
}

\author{
M. Slabbert \\ Department of Jurisprudence \\ University of South Africa \\ PRETORIA \\ E-mail: slabbm@unisa.ac.za
}

\begin{abstract}
Combat organ trafficking - reward the donor or regulate sales
\end{abstract}

There is an acute shortage of transplantable human organs worldwide. The current systems of organ procurement cannot supply in the demand. A new approach is imperative. While countries struggle to find ways of motivating more people to become organ donors, the international illegal black market is thriving. A possible solution to the problem in South Africa might be to change current legislation by confirming human organ trafficking a specific crime as is the case in the United Kingdom. However, more available organs for transplantation in the current recognised system are also essential. To achieve this, it is proposed that donors should be rewarded more effectively, or a regulated market in human organs should be allowed.

\section{Opsomming}

\section{Bekamp onwettige orgaanhandel - beloon die skenker of wettig 'n gereguleerde orgaanmark}

Daar is wêreldwyd 'n geweldige tekort aan oorplantbare menslike organe. Die wyse waarop organe tans verkry word, kan nie in die aanvraag voorsien nie. 'n Nuwe benadering het noodsaaklik geword. Terwyl organisasies in verskeie lande spook om mense te motiveer om vrywillig organe te skenk, floreer die

1 Recognition is given to $\mathrm{C}$ Watson whose unpublished L.L.M. thesis "The organised crime of organ trafficking" (2006, University of the Free State), inspired me to write this article. I am also indebted to emeritus Prof. A.P.J. Roux (philosophy) for his assistance; I of course remain responsible for any flaws. 
internasionale swartmark in orgaanhandel. In Suid-Afrika is een moontlike oplossing om huidige wetgewing te verander deur orgaanhandel 'n spesifieke misdaad te maak, soos in die Verenigde Koningryk. Meer organe vir oorplanting is egter in die erkende stelsel noodsaaklik. Om dit te bereik, word beter vergoeding aan skenkers aanbeveel, asook die toelating van 'n gereguleerde orgaanmark.

\section{Introduction}

Less than a century ago it was unthinkable to take a part from one human being and transplant it into another and that both of them could live afterwards. Today kidney transplants are nearly routine operations in many hospitals, although the development in medical technology cannot as such guarantee the availability of organs for transplantation. All the current methods of organ procurement have failed worldwide to supply in the demand. As a result, flourishing black markets in human organs ${ }^{2}$ have developed worldwide (Kishore, 2005:362), also involving South Africa. It has therefore become a serious problem to secure sufficient transplant organs both to satisfy the need of very ill patients and to combat criminal activities in this field.

The main aim of this article is to argue that monetary compensation to organ donors has become a must in the transplant business firstly, to secure more (hopefully enough) legal organs to satisfy transplant needs, and secondly, in this way to curb illegal organ trafficking. An indication will be given of the acute shortage of transplant organs worldwide and it will be shown that various legalised procuring systems are unsuccessful. This is done by indicating the organ needs in different countries and by discussing the relevant systems which left the deficits. It is also shown that such acute and continuous shortages leave a gap for illegal organ trafficking. The time has arrived for a new way of thinking about the way in which transplantable organs are to be secured.

The phenomenon of illegal organ trafficking will then be discussed. As this is clearly a business, a discussion of the monetary value attached to different human organs is a starting point. Although the

2 For the purpose of this article, organs refer to vital solid organs: kidneys, heart, liver, lungs and pancreas, but reference to organ trafficking is trafficking of kidneys, because the removal of all other vital organs requires the donor (seller) to be dead. 
data is insufficient, it is clear that organ trafficking is serious and that drastic counter measures are necessary - particularly to protect desperate patients and tricked donors. This raises two issues: the content and impact of relevant legislation, and a different, more effective system for procuring sufficient transplant organs in a legal way. The South African health legislation which deals with transplant issues is outlined and discussed; reference is also made to other legislation which has a bearing on organised crime. In this discussion the British health legislation will be highlighted to indicate the shortcomings in the South African legislation.

As a possible solution to the problem of insufficient transplant organs, it will be suggested that a system of monetary compensation to voluntary donors be implemented. As this might not be sufficient to achieve what should be achieved, another proposal is that an organ market be legalised, i.e. that buying and selling of organs by patients and willing sellers be allowed, but regulated. The article ends with arguments dealing with some objections, particularly moral objections, to such a system.

\section{Organ shortages and insufficient procuring systems}

The shortage of transplantable organs is not necessarily linked to the system of organ procurement in a specific country. In fact, no procuring system can meet the demand. To procure organs the United States of America (Goodwin, 2006), the United Kingdom (Haddow, 2006:324-328) and South Africa, among others, follow a system of "opting-in" where the individual on a voluntarily basis, altruistically donates organs (Slabbert \& Oosthuizen, 2007b:311-312). A person's decision to be a donor is indicated by signing a donor card or by simply informing your next of kin about the decision to donate your organs (Blackbeard, 2003:47-48; Cohen, 1989:2). Unfortunately "the most significant aspect of this method of procuring transplant organs is its clear failure to secure anywhere near the number of organs that are required" (Goodwin, 2006:9-10, 39, 57-83; see also Taylor, 2005:5).

In South Africa in 2006 only 829 transplants (solid organs as well as corneas) were performed, whereas approximately 3500 people were waiting for an organ. 3 In 2002, 1628 transplants were per-

3 South Africa has a public and a private health sector. The statistics are for both the sectors. There is also no national waiting list for patients waiting for an organ in South Africa. The figure is therefore an estimate alone (Goldstone, 2007:7). 
formed; in 2003, 1 428; in 2004, 1047 and in 2005, 1 084. There was thus a decrease of 49\% from 2002 to 2006 (Goldstone, 2007:7; King, 2007:5). This decrease is significant as there is a need to transplant at least 1000 kidneys per year. In 2005 and 2006 less than a quarter of these desperately needed transplants were performed. 4

Although the United Kingdom follows a system of "opting-in", health workers always approach the family of a deceased person for their consent before removing the organs. Statistics show that, if the family did not know how the deceased would have thought about an organ donation, $30 \%$ will not consent to an organ removal (Haddow, 2006:324). In 1994 the National Health Service introduced an Organ Donor Register in which an individual can record his/her wish to be an organ donor. The reasoning behind the register was that it might reduce the number of relatives refusing a donation, hence increasing the availability of organs. Indications show that this scheme had limited success (Haddow, 2006:324).

In the United States of America in 2004, 86173 people were on the nation's organ transplant waiting list, 17 patients died every day while waiting for an organ, whereas 115 patients were added daily to the waiting list (Kishore, 2005:362). In 2006 more than 93000 patients were in need of an organ transplant, but only 14699 transplants were done (Statz, 2006:1677-1678). Apart from the "opting-in" system, some states in America also follow a system known as "required request" (discussed fully in Slabbert \& Oosthuizen, 2007a:47; see also Fourie, 2005). In this way of organ procurement, a person is asked to become an organ donor when admitted to a hospital. Despite the fact that both of these systems try to motivate donors, there is still a dire need for transplantable organs and the demand far outnumbers the supply (Goodwin, 2006:6). ${ }^{5}$

The organ shortage is just as critical in Europe. In 2004 Austria, Belgium, Luxemburg, Germany, the Netherlands and Slovenia form part of the Euro transplant area - an organisation of the European

4 Statistics are available on the website of the Organ Donor Foundation - a nongovernmental organisation in South Africa educating the public on organ donations (http://www.odf.org.za.).

5 "Those who can avoid America's transplantation system will do so. They will bypass the American waitlist process for greater access abroad, even if that choice involves paying a destitute living donor and violating the law." (Goodwin, 2006:6.) 
Union which monitors organ transplant activities - 15585 people were on a waiting list. This is interesting because Belgium and Austria follow a system of "opting-out" (Taylor, 2005:24, n23) to cope with the organ shortage. According to this system all citizens of a country are considered organ donors unless the contrary is proved (Slabbert \& Oosthuizen, 2007a:46). The main problem with this way of procuring organs is that it enables the state to take a person's property 6 without his/her consent which might undermine personal autonomy (Taylor, 2005:23). 7 The success of this way of procuring organs is also dependent on an effective national data base that will enable medical staff to find out quickly whether a deceased person has indicated his/her unwillingness to be an organ donor, should the situation arise that his/her organs could be used for transplantation. In general, we may conclude that it doesn't look as if such a "compulsory" system contributes to a substantial difference to the acute shortage of organs.

Finally, statistics in India could also be highlighted as there are periodic reports of organ trafficking in India involving doctors, middlemen and even state officials. Although there are no reliable statistics on the shortage of organs in India with its population of nearly 1,2 billion people, it is estimated that the requirement for kidney transplants is around 80000 per year (150 000 patients are diagnosed with kidney diseases yearly) (Statz, 2006:1679), but not even 5000 kidney transplant operations are performed annually (Kishore, 2005:362). The number of kidney transplants fell from an estimated 3600 per year in 2002 to 2800 per year in 2003 (Statz, 2006:1679).

Although the above statistics cover only a few countries, it clearly underlines the organ shortage worldwide and the failure of current organ procurement systems which leaves an opening for illegal practices to meet some of the demand. Statistics do not have meaning if they are not interpreted. It could therefore be meaningful to link the numbers to a monetary value for each organ. By doing this, it might become clear why organ black markets and syndicates involved in organ trafficking are active in this field.

6 Property rights in human organs are a separate debate and will not be covered in this article, for a discussion on the topic see Slabbert and Oosthuizen (2007a: 5255; see also Charo, 2006:1517-1519).

$7 \quad$ "How can a dead person 'opt-out'? How can the uninformed relatives 'opt-out'? There is no 'opt-out' card. Without a real opportunity to refuse donation, presumed consent looks more like a compulsory form of donation." (Goodwin 2006:16-18, also 117-131.) 


\section{The monetary value of transplantable human organs}

There are no specific documented values for human organs as the commercialisation of human organs is forbidden in most countries. 8 Nobel laureated (economics) Gary Becker and his co-worker, however, established a "market price" for a live donor kidney as a commodity. They are assuming that an American with a life valued at $\$ 3$ million, earning $\$ 40000$ annually, faces a 1\% risk of death from nephrectomy (kidney disease). The American will experience a $5 \%$ decrease in quality of life and a loss of $\$ 7000$ in income due to convalescence from surgery. Therefore a kidney's price could be calculated at $\$ 45000$. Using a more probable death risk of one in 300 nephrectomies (the true reported risk is three in 10000 ), the calculated kidney price reduces to $\$ 20000$ (Friedman \& Friedman, 2006:961). Amounts stated in media reports ${ }^{9}$ give an indication of what an organ (mainly kidneys) could cost on the black market. For South Africa it was reported that a patient in need of an organ could pay up to $\$ 200000$ for an illegal transplant operation (Liebenberg, 2003:3), which will include transport costs to another country, medical fees as well as the cost for the organ. A syndicate operating in South Africa which apparently preyed on poor people in Brazil and Israel, offered their "clients" about \$10 000 per kidney which was then sold for up to $\$ 120000$ (Broughton, 2003a:1; Goodwin, 2006:158-159). The British Broadcasting Corporation reported on impoverished Indians in Madras who were exploited by organ vendors. One poor woman had earned $\$ 750$ for a healthy kidney, whereas the recipient, a Singaporean, paid \$37 000 for it, most of which went to the middleman (BBC News Online, 2002).

8 See a table of legislation banning organ sales in other countries in GarwoodGowers (1999:ix; see also Taylor, 2005:12). The kidney trade is legal and regulated in Iran. The trade is organised and controlled by two government-endorsed NGOs. Regulations have also been put into place to prevent transplant tourism (Ram, 2002). See also "Pakistan's lucrative kidney trade" - unlike the rest of the world there are no laws restricting the sale of organs in Pakistan and no regulation requiring informed consent of potential donors (CNN, 2007).

9 Reference is made to newspaper articles as the information has not yet been recorded in books or journals. Pearson, $(2004: 5,11)$ stated: “... detailed and accurate information related to removal of organs is lacking, as are any programmes to combat organ trafficking. ... There are no statistics on the extent of kidney trafficking per sé.... There have been no studies regarding the extent of organ trafficking, and as with other forms of trafficking, it is extremely difficult to measure due to its clandestine nature." 
Organs are also advertised on the internet, $\mathbf{1 0}$ some under the cover of being a donation. Advertisements usually read that the donor will be compensated for time lost at work but will not be paid for the organ itself.11 By advertising in this way the advertiser makes sure that no laws are broken, however, if the amounts offered are taken into consideration it seems as if the organ is in fact paid for.

Approximately 5500 kidneys are sold in India every year, with an annual turnover of Rs90 crore (Indian currency) (Watson, 2006:5455). In the United States of America an illegal kidney transplant costs up to $\$ 100000$ and in certain areas of Kenya where the organ trade is flourishing, a person can illegally purchase skin and other organs for over $\$ 1800$ (Watson, 2006:54-55). In Turkey the price of a kidney is approximately $\$ 2700$ and rare organs will trade for as high as $\$ 150000$ per item, while the price for organs in Bosnia is $\$ 68$ 000. Some recipients indicated that they have paid up to $\$ 200000$ extra for the illegal transplant to take place, while the middleman who arranged the sale of the organ, receives an estimated \$55 000 (Watson, 2006:54-55).

Many Saudi kidney patients go to the Philippines for an illegal transplant. The cost of kidney transplants there ranges from $\$ 40000$ to $\$ 50$ 000. About $60 \%$ of this amount goes to the hospital and medical team and the rest goes to the donors (Ananena, 2007). The Kidney Foundation of the Philippines indicated that the donor should not get less than 300000 pesos (about $\$ 6000$ ), however, the black market rate is much lower, with the donor getting only between 75000 to 150000 pesos of which 30000 pesos go to the pocket of the local middleman (Ananena, 2007).

It is clear that human organs have monetary value and at present the vital organs can fetch relative high prices. Given the shortage and the demand for organs, organ trafficking has to be expected.

10 Daniel Tuck of the United Kingdom tried to sell one of his kidneys over the internet to settle gambling debt. He was found guilty of contravening sec. 32 of the Human Tissue Act of 2004 and got a twelve months suspended jail sentence (Times-online, 2007). See also http://www.guardian.co.uk/gambling/story/0. 2078157.00.html (The Guardian, 2007).

11 S 60(4) of the National Health Act 61 of 2003 (South Africa, 2003b) also states that a donor may be reimbursed for reasonable costs incurred by him/her to provide a donation. On 3 September 1999 the bidding for a human kidney offered on the internet auction site eBay hit $\$ 5,7$ million before it was stopped due to broken rules of eBay, prohibiting the sale of organs (Broughton, 2003a:1). 
The present legal situation in South Africa is discussed a little later, but it should be remarked that it is specifically the payments for middlemen who organise these illegal sales as part of a syndicate, operating across borders, that necessitates a review of current legislation.

\section{Organ trafficking}

The most common type of organ trafficking, is cases of people who agree to sell their organs and then enter into a formal or informal contract to do so. However, once the kidney is removed these people are, more often than not, cheated and not paid at all, or they are paid only half, or a fraction of the initially agreed upon price. Organised crime plays a role in the form of brokers and middlemen coercing the poor to sell their kidneys (and corneas) by offering economic incentives. Brokers and surgeons frequently lie about the procedures and consequences of kidney removal. For example, they tell the sellers that "the operation is a minor one, that they can return to work immediately, that one kidney is 'useless' or dormant so this one will be removed etc." (Pearson, 2004:10).

To this we may add that most organised and even non-organised crimes are economically driven as market forces create opportunities for legitimate business as well as organised crime - "They are both operating according to the law of demand and supply, but only at different positions within the spectrum of legitimacy." (Leong, 2004:23.) In other words, as long as there is the huge demand for transplantable organs, there will be a market for illegal sales and there will be illegal entrepreneurs willing to organise such sales, usually on a cash basis.

\subsection{Other countries}

Nancy Scheper-Hughes, a member of Organ Watch - a non-governmental organisation against the sale of human organs, based at the University of California - documented that organ trafficking happened in many parts of the world; notably Argentina, Brazil, Cuba, Israel, Turkey, South Africa, the United States of America, the United Kingdom and India (Ram, 2002). Her research shows that abuses associated with kidney transplants occur all over the world in various forms "... the abuses range from the harvesting of organs from executed prisoners in China to the removal of organs from dead bodies in Argentina and South Africa without the permission and knowledge of the families of the dead" (Ram, 2002). 
She12 met a medical doctor based in the United States of America who arranged for patients around the world to get organs, who remarked: "Don't think of me as an outlaw; think of me as a new version of the old-fashioned marriage broker. I locate and match up people in need." (Scheper-Hughes, 2004.) The reality is that if goods or services happened to be outlawed and there is a demand for them, illegal enterprises will emerge to meet the demand (Leong, 2004:19).

The Transplantation of Human Organs Act 42 of 1994 came into operation in 1995 in India. This Act stipulates that transplants are only allowed between immediate family members. The Act only becomes effective after ratification by the different legislative assemblies of the states under the Indian Constitution. Only 31 States have done so, and five have not - commercial transplants therefore continue to be legal in those states (Jha \& Chung, 2001:242). India is an ideal destination for organ trafficking, for it has a vast impoverished population, there is a lack of effective legislation, as indicated, and there are trained and available surgeons and physicians. There are also a lot of very enterprising middlemen (Jha \& Chung, 2001:246).

There are also reports of transplant tourism from Israel, Saudi Arabia, Oman and Kuwait, initially to India but later to Turkey, Iran and Iraq and recently to Russia, Romania and Moldova, where kidney sellers are recruited (Allais, 2004).

\subsection{South Africa}

In South Africa in 2003 a syndicate 13 involved in the sale of human organs was exposed. An Israeli patient bought a kidney from a Brazilian for R37 000, the middleman who organised the sale received R280 000 (Ekron \& Brits, 2003b:3). In December 2003 one of the Durban co-ordinators of the kidney-selling syndicate who was

12 Scheper-Hughes (2004) has written numerous articles on the organ trade. For an interview with her, see Scheper-Hughes (2004).

13 A syndicate is defined as: (1) A group of individuals or organisations combined or making a joint effort to undertake some specific duty or carry out specific transactions. (2) A group, combination or association of gangsters controlling organised crime or one type of crime, especially in one region of the country. (3) A loose affiliation of gangsters in charge of organise crime. A Gang is defined as a group of persons associated for some criminal or other antisocial purpose http://dictionary.reference.com Date of access: 7 Nov. 2007. 
charged with contravening the Human Tissue Act 65 of 1983 confessed to 78 charges of organising illegal organ transplants for two years. The syndicate operated between Israel, Brazil and South Africa (cf. Ekron \& Brits, 2003b:3; Liebenberg, 2005:14; Broughton, 2003a:1; Ekron \& Brits, 2003a:1; Ayoob, 2004:1; Broughton, 2003b: 5; Power, 2006:6). In 2006 an Israeli businessman who allegedly headed the syndicate was arrested in Germany. He organised more than 100 illegal kidney transplants at the St. Augustine's Hospital in Durban (Power, 2006:6; Goodwin, 2006:187-189). Despite wide media coverage, the charges against the accused and others, with the exception of the few who confessed to contravening the Human Tissue Act (1983), were dropped.

The National Prosecuting Authority defended the withdrawal of the case on the grounds that the state was considering the extradition from Russia of two more suspects and the state had been given numerous witness statements in Israel which needed to be translated from Hebrew in order to further more arrests (Power, 2006:6).

Organ Watch reported that in South Africa dialysis and transplantations have been classified as "tertiary health care" and this is not provided by the state to everyone.14 "Dialysis and transplantation are the privilege of a relatively small section of society that can afford expensive treatment in private hospitals." (Ram, 2002; ScheperHughes, 2003.) South Africa has a private and public health care system. There is no national register where every transplant done is recorded. This leaves the door open for transplants to be performed, especially in the private sector, without any questions asked. It is a requirement in South African hospitals that a donor should be blood related to the recipient or the donor could be a patient's spouse. Yet in the private sector it is possible that few questions are asked or research done to determine whether this is in fact the case. The prospective "donor" (actually the seller) may be coached by the organisers of the transplant to act as a relative of the patient (Broughton, 2003b:5; Nair, 2005:1). Because of this lack of control or direction in legislation, South Africa is labelled an ideal country for illegal organ transplants.

14 In South African public hospitals it is practise to accommodate a patient only until the age of 55 on a dialysis programme if the hospital has enough facilities. The patient should also not have any other illnesses (Pienaar, 2004:6). See also Soobramoney v Minister of Health, KwaZulu-Natal 1997 (12) BCLR 1696 (CC) and a discussion of this case in Slabbert and Oosthuizen (2007b:319-321). 
Organised crime is also becoming a global phenomenon. Nowadays there is a new threat of transnational organised crime (Ram, 2002). ${ }^{15}$ Once again this is exactly what happened in the Durban organ scandal. Development in technology made it easy for the criminals to expand their markets across borders (Israel and Brazil). Again, legislation in this regard is also imperative.

A final remark on the issue of syndicates involved in organ trafficking: organ sales do not happen in isolation; many people are part of the crime, making it easy to be labelled "an organised crime". The question arises whether "organised crime" refers to an act or to a group (Leong, 2004:19).16 On the one hand "organised crime" seems to refer to an act, e.g. the sale of human organs. On the other hand, it also refers to a group of people (offenders) involved in the specific crime, for example in the Durban case - the doctors in the transplant unit, the transplant co-ordinators, the sellers and the middlemen were all involved. It thus seems that "organised crime" should include both the "act" and the people involved - the syndicate. The concept organised is a bit problematic, because it is not clear what organise includes. It may simply refer to a wellplanned operation which is. One can argue that the sale of the organs in Durban was part of organised crime. The group, although it consists only of short term partnerships, operated in a smooth well-planned way; the group thus have all or most of the attributes of other criminal organisations. However, because the people involved usually take part on a cash basis and only as the need arises, one can also argue that the undertaking is as such unorganised, consisting of isolated acts and that different legislation should apply. In other words the question to be answered is whether the Prevention of Organised Crime Act 121 of 1998 or the Prevention and Combating of Corrupt Activities Act 12 of 2004 are applicable here or not. The courts will have to interpret the legislation as it is not clear whether these acts are applicable on syndicates organising human organ trafficking or not (cf. also Burchell, 2006:970-1019 for a discussion on organised crime and the Acts).

15 The future will have to determine whether the International Co-operation in Criminal Matters Act 75 of 1996 is applicable in organ trafficking or not.

16 For definitions on organised crime see Burchell (2006:974-976). 


\section{Legislation concerning organ transplants}

\subsection{South Africa}

During the interim period, the Human Tissue Act 65 of 1983 regulates the procurement of human organs in South Africa. In the near future the National Health Act 61 of 2003 will regulate it. 17

\subsubsection{The Human Tissue Act 65 of 198318}

As indicated earlier, South Africa has an "opting-in" system of organ procurement. Section 2 of the Act explains who may donate organs of a deceased person and under which circumstances (Blackbeard, 2003:47-48). The moment of death is not addressed in the Act and this Act does not recognise brainstem death as death. ${ }^{19}$ This is a shortcoming in the Act as the moment of death is extremely important in the transplant context - all organs except for a kidney, may only be removed from a person's body for transplantation purposes, if he/she is declared brain dead and the blood circulation continues albeit by artificial means.

Section 18 of the Act prescribes how a living person may donate an organ (a kidney). It is practice in South African hospitals to accept donations from living persons only if they are related by blood to the patient in need of a transplant, or if the donor is the patient's spouse. If the source of the donation is a friend or an altruistic acquaintance, an application has to be made to the Department of Health, who will investigate the matter and only after it has been determined that the donation is not for financial gain, permission will be granted for the operation to be carried out. This is because section 28 of the Human Tissue Act (South Africa,1983) prohibits the payment for donated

17 The National Health Act with the exception of several chapters (including Chapter 8 on organ transplants) came into effect on 2 May 2005. Section 93(1) of the Act repeals the Human Tissue Act in total, but it will only be done on a date fixed by the President in a Government Gazette. In the interim the Human Tissue Act and its regulations remain in force.

18 For a detailed discussion on the Human Tissue Act as well as the National Health Act, and the influence of the Constitution of the Repulblic of South Africa (1996) on these Acts, see Slabbert and Oosthuizen (2007b:304-323). Note also that mentioning the Human Tissue Act is relevant as the contraventions of illegal trade in human organs in South Africa occurred when this Act was still effective.

19 See S 7(2) of the Human Tissue Act (South Africa, 1983) for an explanation on how death should be determined. See also Slabbert (2002) for a discussion on brain death. 
organs. It is accepted that family members or spouses will not charge the patient for the organ, but strangers might have other motives.

In terms of section 28 of the Act (South Africa, 1983) it is thus illegal to sell or buy an organ. This allegedly happened in at least 109 kidney transplants done at St. Augustine's Hospital between June 2001 and November 2003 (Kockot, 2005). Apart from transgressing the law, this alleged trafficking of donors into South Africa also contravened an international protocol aimed at preventing the trafficking of people for exploitation, including the removal of their organs. The South African government and more than 80 other countries signed the Palmero Protocol in December 2000 in an effort "to prevent and suppress the trafficking in human persons" (Kockot, 2005). The definition for human trafficking includes the recruitment of persons by deception, abuse of power or position of vulnerability, or the giving of payments or benefits to achieve the consent of a person for the purpose of exploitation.

Exploitation shall include, at a minimum, the exploitation or the prostitution of others or other forms of sexual exploitation, forced labour services, slavery or practices similar to slavery, servitude or the removal of organs (emphasis - MS). 20 (United Nations, 2000.)

Article 5 of the Protocol requires that countries that signed the Protocol must adopt such legislative and other measures that may be necessary to establish as criminal offences the conduct set forth in this Protocol, when committed intentionally. This means that had South Africa introduced legislation to support this Protocol, people allegedly involved in recruiting kidney donors (sellers) might also have faced charges of human trafficking (Kockot, 2005). At this stage, no such laws exist, although the Department of Health has indicated that legislation governing live donor transplants will be tightened. 21

20 Art. 3 of the Protocol: "To prevent, suppress and punish trafficking in persons, especially women and children, supplementing the United Nations convention against transnational organized crime." (Palmero Protocol; United Nations, 2000.)

21 See also Pearson (2004): at 6 "Criminal Laws should be amended so that brokers and medical staff involved in transplantation procedures are criminally responsible whilst donor-sellers are specifically free from criminal responsibility unless directly involved in trafficking others." And: at 7 "National laws should be modified in order to prevent abuse of organ transplantations." 


\subsubsection{The National Health Act 61 of 2003}

The National Health Act recognises brainstem death as death (see s. 1: "Definitions": death is brain death; South Africa, 2003b). Section 62 of this Act lists the same requirements for an organ donation from a deceased body as the Human Tissue Act. 22 Section 55 prescribes how a living person may donate an organ.

An interesting difference between the National Health Act and the Human Tissue Act is section 60, concerning the payment in connection with the acquisition of an organ. Section 60(4)(a) states that a donor of an organ may be reimbursed for reasonable costs incurred by him/her in relation to the donation. "Reasonable costs" are not defined in the Act. This will hopefully be done in the Regulations to follow the enactment of chapter 8 of the National Health Act 61 of 2003. If reasonable costs are not defined in the Regulations to follow, the door will again be open for illegal payments for organs as costs paid for the donations might include an amount for the organ itself.

\subsection{The United Kingdom}

\subsubsection{Human Tissue Act 2004 (c. 30)}

The Human Tissue Act which received Royal assent on 15 November 2004 repealed and replaced the Human Organ Transplantation Act of 1989 that was passed in response to a scandal involving the removal of kidneys from Turkish citizens for the benefit of British patients (Harrington, 2006). The Human Organ Transplantation Act prohibited commercial dealings in organs, including trafficking between other countries and Britain. "Notwithstanding these measures, organ tourism from Britain to Third World countries was flourishing." (Harrington, 2006.)

The Human Tissue Act 2004 specifically prohibits dealing in human material for transplantation. The purpose of the Act is to provide a consistent legislative framework for issues relating to whole body donation and the taking, storage and use of human organs and tissue. Consent is made for the fundamental principle underpinning the lawful storage and use of human bodies, body parts, organs and tissue and the removal of material from the bodies of deceased

22 For minor differences between the two acts see Slabbert and Oosthuizen (2007b:306-311.) 
persons. The Act arose from concern raised by events at Bristol Royal Infirmary and the Royal Liverpool Children's Hospital (Alder Hey) in 1999-2000. The Kennedy and Redfern inquiries at these hospitals established that organs and tissue from children who had died had often been removed, stored and used without proper consent. A subsequent census by the Chief medical officer for England (2000) and the Isaacs report (2003) (United Nations, 2000) showed that storage and use of organs and tissue from both adults and children without proper consent have been widespread in the past.

The section on trafficking, section 32, transposes the prohibition on buying and selling organs from the Human Organ Transplant Act, and extends the prohibition to cover all human material (subject to certain exceptions) intended to be used for transplantation. Subsection (1) stipulates that a person commits an offence if

- he gives or receives a reward for the supply of or for an offer to supply any controlled material;

- seeks to find a person willing to supply any controlled material for reward;23

- offers to supply any controlled material for reward;

- initiates or negotiates any arrangement involving the giving of a reward for the supply of, or for an offer to supply, any controlled material;

- takes part in the management or control of a body of persons corporate or unincorporate whose activities consists of or include the initiation or negotiation of such arrangements.

According to subsection 2 advertising for suppliers of material for reward is also prohibited. Subsection 7 provides that reimbursement for expenses connected with transporting, removing, preparing, preserving or storing the body of a deceased person or relevant human material is not prohibited. The section also provides that it is not an offence to provide expenses or recompense for loss of earnings given to an individual supplying human material and it allows for costs incurred by others to be passed along a chain of suppliers (Anon., 2007). In other words, according to this new legislation in the United Kingdom a donor may be compensated for reasonable costs

23 Reward in the Human Tissue Act 2004 means any description of financial or other material advantage (S 32(11); United Kingdom, 2004.) 
incurred with the donation, similar to the position of the National Health Act in South Africa.

If the South African Human Tissue Act is compared to the Human Tissue Act of the United Kingdom there is a definite shortcoming in South African law - British legislation addresses the crime of organ trafficking, but it is not addressed in South African law. In South Africa the crime of paying for human organs is defined in legislation of the Department of Health instead of it being described as a crime by the Department of Justice.

\section{Possible solutions to the crime of illegal organ sales}

The shortage of transplantable organs is a fact proven by the number of patients on waiting lists. These numbers unfortunately do not tell the full story about the shortage - especially with reference to kidneys, as the statistics do not indicate the number of patients on dialysis either at home or on hospital programmes. Neither do the statistics indicate all the other patients waiting for other vital organs. The waiting lists are merely a reflection of those patients who ended up with the right medical practitioners. Current methods of organ procurement have failed to supply in the demand and the call for change are becoming louder and louder. One alternative is to consider implementing financial incentives to donors (Haddow, 2006: 324). Such a move will, however, still not guarantee enough organs. Other alternatives should be available for those with greater financial resources and thereby freeing altruism to work for those who are truly the most vulnerable, particularly economically disenfranchised patients (Goodwin, 2006:40).

If direct commercialisation of human organs is unacceptable to countries, they should at least consider compensating the donor, as this does not necessarily lead to the donor being exploited. Expecting the donor to take the trouble, the pain, et cetera to donate a kidney on an unpaid basis is exploitative (Radcliff-Richards, 1991: 190-192). Most jurisdictions, including South Africa, do not provide for any compensation of donor losses as a matter of right. "It leaves some donors suffering a 'double whammy' of physical damage and financial hardship from their activities and this is totally unacceptable." (Garwood-Gowers, 1999:192; cf. also Blackbeard 2002:5283.)

Garwood-Gowers (1999:192-193) proposes that the donor should at least be compensated for the pain and suffering, the "labour" similar to rates given to medical research volunteers, their normal wage that 
they would earn daily, travel expenses to and from the hospital (also during the testing phase), childcare - if the donor is a mother and she has to pay someone to look after her children - and accommodation, if applicable.

As indicated earlier, the new National Health Act in South Africa and the Human Tissue Act in the United Kingdom provide for "reasonable costs" to be paid in connection with a donation. Although this is definitely a step in the right direction it also raises concerns as to who will control/investigate the fees paid and who will determine the reasonableness thereof? Will it be possible to conceal within the amount paid a sum for the organ itself? In short, though such a system of compensation does not raise serious ethical or humanitarian concerns - in fact it seems the moral way to go - it does lead to all kinds of financial and regulative problems which will have to be considered carefully. However, if monetary compensation is in order, and seeing that South Africa is a free market country, the question is whether we should not go the whole way and legalise organ sales by regulating such a practice.

Arguments against the sale of human organs are not new and they seem to be similar worldwide (Pearson, 2004:15-27). The most common arguments are that the autonomy of the poor will be compromised, that removing an organ is harmful, that the sale of organs will commodify human beings which will violate human dignity and lastly the vague argument that selling organs is unethical or immoral.24

Considering the arguments that selling an organ is unethical or that an organ market is immoral, different answers can be argued. Firstly, regarding the illusion of a morality of scale, Friedman and Friedman ask "Just what is so ethically wrong?" They continue by asking why it is worse to sell a kidney than selling sperm or egg cells, as the latter two should be more morally questionable than organ sales because those cells might create an entirely new human being (Friedman \& Friedman, 2006:961-962). According to Beauchamp (2003:272) two moral questions about selling kidneys need to be answered, namely: Will it always be morally wrong for an individual to sell a kidney? And, is there an adequate moral basis to justify the commercialisation of organs? With reference to the first question, he is convinced that such a generalisation cannot hold water. This is

24 For an in depth discussions on all these points of criticism see Slabbert and Oosthuizen (2007a:55-60). 
the demand that moral sales allow no exception. Beauchamp (2003:272) uses the following example:

Suppose that my wealthy cousin will perish without a kidney; he offers me $\$ 100000$ for one of mine. I am well informed about the current and lifetime risks of nephrectomy, and I could put the $\$ 100000$ to good use in reducing a burdensome mortgage. I understand my cousin well, and he understands me equally well. Limitation of our liberty would require a compelling justification for preventing us from entering into a relationship that will benefit me financially and will save his life.

The dilemma gets even more troublesome when another life is at stake. Say instead of a mortgage the possible donor has to pay for life saving heart surgery on his child?

With a market for kidneys Beauchamp (2003:272) has certain reservations depending on whether it is a local open market, a regulated market or an international market. Irrespective of the market at hand, he came to the conclusion that the selling or purchasing of a kidney need not involve disrespect for persons and is not in itself a ground for moral repulsion or indignation. What worries him more is that markets in organs might invariably lead to some form of exploitation.

De Castro (2003:142) differs by saying that compensation for organs does not necessarily lead to exploitation - on the contrary, it may be regarded as a necessity in efforts to minimise the level of exploitation that already exists in the current organ procurement systems.

\section{- Exploitation of the poor}

Many authors have expressed concern that the poor will be so focused on the money they will receive for their organ that they will not understand the procedure and the risks involved with the removal of a kidney. Money and intellect are not dependant on each other; poor people are not necessarily ill informed or unable to consent. Moreover, poor people also have rights and dignity. Good medical practice demands proper counselling in order for a donor to give informed consent (Savulescu, 2003:138-139). The medical tests and procedures also ensure that the donors are cared for and that there is time for reflection. Beauchamp (2003:272) sums it up by saying "those who sell their kidneys are at risk of exploitation, it does not follow that a ban on the sale of kidneys is the best way to address these problems". 


\section{- Removing an organ is harmful (Wilkinson \& Garrard, 1996:334)}

People are allowed to donate an organ only after medical tests have been done and doctors are satisfied with the health status of both the patient and the organ. The fact that money exchanges hands should make no difference to professionalism where everything is above board (Slabbert \& Oosthuizen, 2007a:57). Research done at Minnesota University in the United States of America showed that a person could have a healthy life with one kidney and that the removal of a kidney doesn't necessarily have a negative impact on a donor (Rothman, 1998:15).

\section{- Commodification of the human body}

Commodification of the body is difficult to describe. Are undertakers commodifiers of the body? What about opera singers who "sell" and "live by" their voices? They even insure it. Body parts are already commodified on black markets (Savulescu, 2003:138). Donors and recipients have been negotiating terms of organ transfers with or without the sanction of legal authorities. "In a way it is the undeniable existence of the demand and the corresponding supply that commodifies human organs even before anyone tried to put a price tag on to [sic] them" (De Castro, 2003:145). Commodification is a fact. People sell their labour (in that sense themselves), make money with their voices, et cetera. This seems an arbitrary boundary. That it is a fact does not say it is right, but at what stage, under what circumstances does it become wrong?

As long as human organ sales are not prosecuted everywhere or criminalised only in some countries the black market for selling organs will not stop. In this era of instantaneous communication through the internet and air travel being relatively cheap, needy patients will look beyond borders and laws imposed by their own countries. If they can legally buy a kidney at home and pay a fair price excluding a middleman not only will they benefit, but the organ shortage especially for kidneys might be alleviated.

All these objections tread on moral sensitivities. In other words, the basic question is whether a regulated, legal organ market can be morally justified. To answer this question we have to bear in mind that we live in a multi-cultural society and a direct answer cannot be given. There are many ethical perspectives, approaches and different values. Cottingham (1998:20) with his idea of "a committee 
ethics" and Engelhardt25 (1992:12) with his idea of "limited (moral) solidarity" help one to get to some answer by emphasising the value of ongoing fundamental discussion so as to reach some kind of consensus - a general, rather vague, set of principles which provide a common framework whilst leaving sufficient lee-way to different approaches. In South Africa our constitution which is the outcome of exactly this kind of negotiation and thus a form of "committee ethics" or "limited solidarity" provides us with a sort of common moral system and common values. The nearest we can get to an answer about moral acceptability of legal organ sales is to test it against the Constitution and the Declaration of Human Rights. It fits the basic right to life which has an active side 26 as in self-defence - a patient has to be in a position to contribute to, take part in his staying alive and ensuring a certain quality of life. It further allows for personal autonomy in two ways. The patient whose life depends on a transplant can do something he/she can actively participate in by trying to find a willing seller. On the other hand, there is no compulsion; it is for the patient to decide which option he/she wants to choose. In short, to allow a market is the just way to go. To deny a terminally ill patient the opportunity to participate actively in a search for a vital organ even if it includes payment, constitutes a form of dogmatic oppression which would be unjust. The same applies in the case of the willing seller who should not be deprived of an opportunity to improve his/her position. Thus, justice demands that the market option should be available to those who wish to use it.

\section{Conclusion}

At the beginning of this article it was indicated that there is a worldwide shortage of transplantable organs. The current methods

25 Engelhardt (1992:12) concludes commercialisation of organ transfers is not per se wrong. "In the absence of an appeal to the particular religious or ideological understanding the proper role of commerce in organs and bodies, there will not be a way to determine when commercialisation in human organs is morally improper."

26 See in this regard specifically O'Reagan in S. v Makwanyane 1995(3) SA 391 (CC) para 326 where the "right to life" is framed in terms which go beyond traditional conceptions of the right not to lose one's life at the hands of the state to embrace the right to live with dignity: "the right to live as a human being, to be part of a broader community, to share in the experience of humanity". See also Slabbert (2002:75-78) and for an in depth discussion of medical ethics and the sale of human organs, see Slabbert and Oosthuizen (2007b:314-321). 
of organ procurement cannot supply in the ever increasing demand. Altruism may be the noblest form of giving, especially in the context of organ donation, but how many people have to die before we rethink our procurement strategy? (Goodwin, 2006:9). "The incompetence of altruism has meant service for some and death for many others." (Goodwin, 2006:40.)

Black markets are flourishing to the detriment of the person giving up his/her kidney, as the middlemen seem to be the parties benefiting the most financially. These illegal practices will not end, but will continue to thrive until it is replaced with a viable alternative (Goodwin, 2006:190). Technology has also made it easier to look for organs across borders and therefore black markets are not linked only to specific countries. The crime of organ trafficking, whether it exists or whether it is only a few isolated incidences, needs to be stopped (Garwood-Gowers, 1999:191).

A few suggestions for combating illegal organ sales in South Africa have been proposed. The first possibility is to change the system of organ procurement to that of "opting-out" - the negative aspects of such a system have also been highlighted. Another solution may be tighter applicable legislation for example, to make organ trafficking a specific crime or to make acts like the Prevention of Organised Crime Act directly applicable to illegal organ sales. For the present, it is not clear who is criminally responsible for the crime of organ trafficking. The problem is furthermore that offenders are never really discouraged by legislation forbidding certain actions; they just use certain loopholes to by-pass the law.

Two better alternatives are to compensate the donor or to legalise the sale of human organs by regulating it nationally and internationally (Harrington, 2006; also Josefson, 2002:446).

\section{List of references}

ALLAIS, C. 2004. Human trafficking as 21st century from slavery. http://lsa.unisa.ac.za/news/arch/august/vol4/human.html Date of access: 23 Apr. 2007.

ANANENA, J. 2007. 2400 Saudis on waiting list for kidney transplant operation in the Philippines. The Saudi gazette: 9 Feb. http://www.saudigazette. com.za/index Date of access: 22 Feb. 2007.

ANON. 2007. Explanatory notes to Human Tissue Act. 2004. http://www. opsie.gov.uk/acts/en2004/04en30-a.htm Date of access: 8 Nov. 2007.

AYOOB, Z. 2004. Organ trade: trio in court. Natal witness: 1, 24 Jan.

BBC NEWS ONLINE. 2002. Indians selling human organs, 15 October. http://www.news.bbc.co.uk Date of access: 22 Feb. 2007. 
BEAUCHAMP, T.L. 2003. Methods and principles in biomedical ethics. Journal of medical ethics, (29):269-274.

BLACKBEARD, M. 2002. Organ donation for profit. Obiter, (23):52-83.

BLACKBEARD, M. 2003. Consent to organ transplantation. Tydskrif vir hedendaagse Romeins-Hollandse reg, (66):47-48.

BROUGHTON, T. 2003a. Police smash cash-for-kidneys syndicate which made use of private Durban hospital. Cape times: 1, 4 Dec.

BROUGHTON, T. 2003b. Hospital staff linked to illicit kidney donor deals. Star: 5, $11 \mathrm{Dec}$.

BROUGHTON, T. 2005. Kidneys for sale - former staffer "implicated". Star: 2, 19 Sept.

BURCHELL, E.M. 2006. Principles of criminal law. Juta: Cape Town.

CHARO, R.A. 2006. Body of research: ownership and use of human tissue. New England journal of medicine, 355(15):1517-1519.

CNN. 2007. Pakistan's lucrative kidney trade. http://www.edition.cnn.com Date of access: 26 Feb. 2007.

COHEN, L.1989. Increasing the supply of transplant organs: the virtues of a futures market. The George Washington law review, (58)1.

COTTINGHAM, J. 1998. Philosophy and the good life: reason and passions in Greek, Cartesian and psychoanalytic ethics. New York: Cambridge University Press.

DE CASTRO, L.D. 2003. Commodification and exploitation: arguments in favour of compensated organ donation. Journal of medical ethics, (29):142-146.

EKRON, Z. \& BRITS, E. 2003a. Kidney trade: men nabbed in Durban. Natal witness: 1, 4 Dec.

EKRON, Z. \& BRITS, E. 2003b. Twee in arres oor gesmous met organe. Beeld: 4, 3 Des.

ENGELHARDT (jr), H.T. 1992. The search for a universal system of ethics: post-modern disappointment and contemporary possibilities. (In Kjellstrand, M. \& Dossetor, B., eds. Ethical problems in dialysis and transplantation. Kluwer: Dordrecht. p. 2-15.)

FOURIE, E.J. 2005. An analysis of the doctrine of presumed consent and the principles of required response and required request in organ procurement. Pretoria: University of Pretoria. (L.L.M. thesis.)

FRIEDMAN, E.A \& FRIEDMAN, A.L. 2006. Payment for donor kidneys: pros and cons. Kidney international, (69):960-962.

GARWOOD-GOWERS, A. 1999. Living organ transplantation: key legal and ethical issues. Ashgate: England.

GOLDSTONE, C. 2007. Need great, but organs few in SA. Pretoria news: 7, 18 Aug.

GOODWIN, M. 2006. Black markets: the supply and demand of body parts. Cambridge: New York.

GUARDIAN. http://www.guardian.co.uk Date of access: 12 Nov. 2007.

HADDOW, G. 2006. "Because you're worth it?" The taking and selling of transplantable organs. Journal of medical ethics, (32):324-328.

HARRINGTON, J. 2006. Legal aspects of organ transplantation in health services. http://www.imlab.ac.uk/harrington.htm Date of access: 19 Oct. 2007.

JHA, V. \& CHUNG, K.S. 2001. India. (In Levinsky. Ethics and the kidney. Oxford: Oxford University Press. p. 241-254.) 
JOSEFSON, D. 2002. United States to consider paying organ donors. British medical journal, (324):446.

KING, K. 2007. Transplants on rapid decrease. Rekord East: 5, 27 Jul.

KISHORE, R.R. 2005. Human organs, scarcities and sale: morality revisited. Journal of medical ethics, (31):362-365.

KOCKOT, F. 2005. Kidney scandal: call for change to law. Sunday tribune. http://www.tribune.co.za Date of access: 19 Oct. 2007.

LEONG, A.W.M. 2004. Definitional analysis: the war on terror and organised crime. Journal of money laundering control, 8(1):19-36.

LIEBENBERG, D. 2003a. R317 000 vir smokkel-nier. Beeld: 3, 6 Des.

LIEBENBERG, D. 2003b. Geldelike knyp lei tot smokkelary met organe. Beeld: 4, 11 Des.

LIEBENBERG, D. 2005. Organe glo ook in Jhb, Kaapstad gesmokkel. Beeld: 14, 16 Feb.

NAIR, N. 2005. Kidney trafficking case: top Durban surgeons in court. Natal witness: 1, 17 Aug.

ORGAN DONOR FOUNDATION. http:www.odf.org.za

PAKISTAN'S LUCRATIVE KIDNEY TRADE. http://www.edition.cnn.com Date of access: 26 Feb. 2007.

PEARSON, E. 2004. Coercion in the kidney trade? A background study on trafficking in human organs worldwide. http://www.gtz.de/de/dokumente/ en-svbf-organ-trafficking-e.pdf Date of access: 11 Dec. 2007.

PIENAAR, A. 2004. Dialise by staatshospitale net gegee as iemand sterf of nier kry. Beeld: 6, 22 Apr.

POWER, M. 2006. Key arrest in kidney trade case. Sunday times: 6, 13 Aug.

RADCLIFF-RICHARDS, J. 1991. For him that hath not. (In Land, W. \& Dossetor, J., eds. Organ replacement therapy: ethics, justice and commerce in organ replacement theory. Berlin: Springer Verlag. p. 190192.)

RAM, V. 2002. International traffic in human organs. Frontline, 19(7):2. http://www.hinduonnet.com/fline/fl1907/19070730.htm Date of access: 22 Feb. 2007.

ROTHMAN, D.J. 1998. The international organ traffic. New York review of books: 15, 26 Mar.

SAVULESCU, J. 2003. Is the sale of body parts wrong? Journal of medical ethics, (29)138-139.

SCHEPER-HUGHES, N. 2003. A grisly global trade: a taboo tumbles: the market for "fresh" human organs is expanding worldwide, with the poor providing for the rich. Los Angeles times: 2, 3 Aug.

SCHEPER-HUGHES, N. 2004. Interview. http://www.threemonkeysonline.com. threemon_article_organ_trafficking_interview Date of access: 11 Jan. 2007.

SLABBERT, M. 2002. Handeldryf met menslike organe vir oorplantingsdoeleindes. Bloemfontein: Universiteit van die Vrystaat. (L.L.D.-proefskrif.)

SLABBERT, M. \& OOSTHUIZEN, H. 2007a. Establishing a market for human organs in South Africa. Part 1: A proposal. Obiter, 28(1):44-69.

SLABBERT, M. \& OOSTHUIZEN, H. 2007b. Establishing a market for human organs in South Africa. Part 2: Shortcomings in legislation and the current system of organ procurement. Obiter, 28(2):304-323. 
STATZ, S.E. 2006. Finding the winning combination: how blending organ procurement systems used internationally can reduce the organ shortage. Vanderbijl journal of transnational law, (39):1677-1709.

TAYLOR, J.S. 2005. Stakes and kidneys: why markets in human body parts are morally imperative. Ashgate: England.

TIMES-ONLINE. http://business.timesonline.co.uk Date of access: 12 Nov. 2007.

UNITED KINGDOM. Department of Health. 2003. The investigation of events following the death of cyril Marks Isaacs, May.

UNITED NATIONS. 2000. Protocol to prevent, suppress and punish trafficking in persons, especially women and children, supplementing the United Nations Convention against transnational organised crime. (Palmero Protocol.)

WATSON, C. 2006. The organised crime of organ trafficking. Bloemfontein: University of the Free State (L.L.M. thesis.)

WILKINSON, S. \& GARRARD, E. 1996. Bodily integrity and the sale of human organs. Journal of medical ethics, (22):334-339.

\section{List of statutes}

SOUTH AFRICA. 1983. Human Tissue Act 65 of 1983.

SOUTH AFRICA. 1996. Constitution of the Republic of South Africa, 1996.

SOUTH AFRICA. 1998. Prevention of Organised Crime Act 121 of 1998.

SOUTH AFRICA. 2003a. International Co-operation in Criminal Matters Act 75 of 1996.

SOUTH AFRICA. 2003b. National Health Act 61 of 2003.

SOUTH AFRICA. 2004. Prevention and Combating of Corrupt Activities Act 12 of 2004.

INDIA. 1994. Transplantation of Human Organs Act 42 of 1994 (India).

UNITED KINGDOM. 2004. Human Tissue Act 2004 (c.30) (UK).

\section{List of cases}

Soobramoney v Minister of Health KwaZulu-Natal 1997 (12) BCLR 1696 (CC)

S v Makwanyane 1995(3) SA 391 (CC)

\section{Key concepts:}

black markets in organs

exploitation of the poor

organ donations

organ procurement

organ shortages 


\section{Kernbegrippe:}

eksploitasie van armes

orgaanoorplantings

orgaanverhandeling/orgaanverkope

orgaanverkryging

swartmark 
